\title{
Determinant Income of Kerawang Gayo Craftsmen
}

\author{
Nurlela $^{1}$, Husaini ${ }^{1}$, Nazir $^{1}$, Nurhasanah $^{1}$ and Wardhiah $^{1}$ \\ \{nurlelanur1104@gmail.com\} \\ ${ }^{1}$ Faculty of Economics and Business, Universitas Malikussaleh, Aceh Utara, Indonesia
}

\begin{abstract}
This study aims to analyse the effect of product diversity, age of business, working capital and Working hours on income of the small industrial Kerawang Gayo Craftsmen in Aceh Tengah, Aceh Province. The data was obtained by distributing questionnaires to 33 respondents who were the samples in this study who were taken using purposive sampling method. The data analysis method used is multiple linear regressions through SPSS programme. The results of this study indicate that business duration, working capital, and working hours have a significant effect on the income of Kerawang Gayo craftsmen in Aceh Tengah. Meanwhile, product diversity does not significantly influence on Income of Kerawang Gayo craftsmen in Aceh Tengah.
\end{abstract}

Keywords: Product Diversity, Business Age, Working Capital, Working Hours, Income

\section{Introduction}

Indonesia is an island nation that has a lot of diversity. The form of diversity looked at multi customs and cultures. These customs and culture are reflected in the foods and clothing whose using. Each tribe and region has their own type of traditional clothing. As a result of the need for increased traditional clothing, craftsmen or small businesses were born to make these traditional clothes. For instance, one of the regencies in Aceh Province is Aceh Tengah has a traditional products called "Kerawang Gayo". These products can categorized into bags, hats, bracelets, men's or women's clothing and several other types of products. These clothing are always used in every traditional parties in Aceh Tengah. Kerawang Gayo provides a very thick traditional image. Later on, Kerawang Gayo are admired because manufacturing process is quite complicated and takes a long time depending on what product is being worked on.

The existence of small micro-business that produces the traditional products, it can increase income of crafsment in Aceh Tengah. The micro- small and medium enterprises are a form of small business community whose establishment is based on individual initiatives where someone wants to improve their standard of living. Based on the pre-survey, gotten the income of craftsmen Kerawang Gayo was different. This can be influenced by the age of business and working capital, (Nazir, 2010; Novrizal, 2011; Meta, 2013; Utami and Wibowo, 2013). In term of these conditions, the researchers want to further assess to find out about increasing of income of the Craftsmen in Aceh Tengah and add the product diversity variable as a differentiator.

\section{Literature Review}

\subsection{Income}

(Kieso, Weygandt and Warfield, 2011) said revenue is the gross inflow of economic benefits arising from the entity's normal activities during a period, if the inflow results in an increase in equity that does not originate from investment contributions. Furthermore, 
according to (Baridwan, 2004, p. 297) income is the inflow or other increase in assets of a business entity or repayment of debt (or a combination of both) during a period that comes from the delivery or manufacture of goods, delivery of services, or other activities which are the main activities of the business entity.

\subsection{Product Diversity}

Products are everything that producers offer to be considered, demanded, sought, bought, used, or consumed as meeting the needs and desires of the market, (Armstrong and Kotler, 1999). Product diversity is a collection of all goods or products offered by certain sellers to buyers, (Kotler and Kevin, 2009). While (Utami and Wibowo, 2013) said product diversity is the number of selected items in each product category. A store with a wide variety of products (large assortment) can be said to have good depth. Product diversity has a positive effect on income, (Novrizal, 2011; Meta, 2013).

\subsection{Age of Business}

The age of business is the length of time the trader works in the trading business that is currently being lived. The length of a business can lead to a business experience, where experience can influence oh behavior of treaders in facing buying and can increase the sell and their revenue. Business age is the dominant variable that influences traders' income because for a long time a businessman pursuing his business will affect his productivity so that it can increase efficiency and reduce production costs less than sales. Business age has a positive effect on income, (Utami and Wibowo, 2013).

\subsection{Working capital}

Working capital is the total current assets owned by the company (Brigham and Houston, 2013). Working capital is an asset. Working capital has a positive influence on income, (Nazir, 2010; Novrizal, 2011; Meta, 2013; Utami and Wibowo, 2013).

\subsection{Working hours}

Working hours are the amount of work time in producing an item. Employee working hours are generally determined by company leaders based on company needs, government regulations, and the ability of the employees concerned. A long period of working will enhance opportunity of trader to increase of selling. Working hours have a positive effect on income, (Meta, 2013).

\subsection{Hypothesis}

H1: Product diversity affects to income of the craftsmen Kerawang Gayo in Aceh Tengah

H2: The age of business affects to income of the craftsmen Kerawang Gayo in Aceh Tengah

H3: Working capital affects to income of the craftsmen Kerawang Gayo in Aceh Tengah

H4: Working hours affect to income of the craftsmen Kerawang Gayo in Aceh Tengah 


\section{Methodology}

\subsection{Data}

This research was conducted on Kerawang Gayo craftsmen in Aceh Tengah Aceh Province. The number of craftsmen is 47 small businesses. The sampling method uses purposive sampling and sample gotten 33 businesses. Data premier used in the research and collected by distributed the questionnaire to the Kerawang Gayo craftsmen in Aceh Tengah.

\subsection{Analysis Method}

Data analysis methods used for multiple linear regressions are processed with the SPSS program, with the following equation:

$\operatorname{LnY}=\mathrm{a}+\beta 1 \mathrm{X}_{1}+\beta 2 \mathrm{X} 2+\beta 3 \operatorname{LnX} 3+\beta 4 \mathrm{X} 4+\mathrm{e}$

Where:

$\mathrm{Y}=$ Income

$\mathrm{X}_{1}=$ Number of Product Varieties

$\mathrm{X}_{2}=$ Age of Business

$\mathrm{X} 3=$ Working Capital

X4 = Working Hours.

\section{Results And Discussion}

\subsection{Classical Assumption}

The results of data analysis about the normality test obtained by the KS value of 0.524 , it can be concluded that the data is normally distributed. Multicollinearity testing also found that all variables had tolerance values above 0.1 and VIF values were below 10 . The heteroscasticity test results also found that data did not occur heteroscedasticity, because the data spread randomly.

\section{2. $\quad$ Regression Analyse}

Regression used to analysis the influence between Number of Product varieties, Age of Business, Working Capital, and Working Hours on income of Kerawang Gayo Craftsmen in Aceh Tengah. The summary of SPSS show in table below:

Table 1. Regression

\begin{tabular}{|c|c|c|}
\hline Variables & B & Sig. \\
\hline (Constant) & .630 & .084 \\
\hline $\begin{array}{l}\text { Product } \\
\text { (X1) }\end{array}$ & .010 & .300 \\
\hline Age of Business (X2) & .009 & $.019 * * *$ \\
\hline $\begin{array}{l}\text { Working Capital } \\
\text { (X3) }\end{array}$ & .665 & $\begin{array}{l}.000 * * * \\
*\end{array}$ \\
\hline Working Hours (X4) & -.032 & $.051 *$ \\
\hline
\end{tabular}

Source: Primary data analysed 2018 
Notes: ***) significant level $1 \%, * *)$ significant level $5 \%, *)$ significant level $10 \%$.

\section{Discussion}

Based on table 1 above, the results of regression analysis found that the value of pvalue for the variable of product diversity (X1) $0.300>0.05$, then rejecting $\mathrm{H} 1$ means that there is no significant influence on income. The Business Duration variable (X2) has a value of $0.019 \mathrm{p}$ $<0.05$, so accepting $\mathrm{H} 2$ means that this variable has a positive and significant effect on income. Likewise, the working capital variable (X3) has a p value of $0.000<0.05$, so accepting $\mathrm{H} 3$ means that the variable has a positive and significant influence on income. Working hours variable (X4) has a value of $0.051 \mathrm{p}<0.01$, then accepting H4 means that the variable has a significant effect on the income of Kerawang Gayo craftsmen in Aceh Tengah, Aceh Province.

\section{References}

[1] Armstrong, A. and Kotler, K. (1999) Prinsip- Prinsip Pemasaran. Jakarta: Erlangga.

[2] Baridwan, B. (2004) Intermedite accounting. Yogyakarta: BPFE.

[3] Brigham, F. and Houston, J. F. (2013) Fundamentals of Financial Management. Thirteenth. Boston: Cengage Learning ALL.

[4] Kieso, D. E., Weygandt, J. J. and Warfield, T. D. (2011) Intermediate Accounting. Volume 1IF. United States: Wiley.

[5] Kotler, P. and Kevin, K. (2009) 'Manajemen Pemasaran. Edisi Kedua Belas, PT Indeks, Jakarta'. Jakarta: Erlangga.

[6] Meta, T. (2013) Pengaruh modal kerja, tenaga kerja, jam kerja terhadap pendapatan nelayan tradisional di nenggari koto taratak kecamatan sutera kabupaten pesisir selatan. STKIP PGRI Sumatera Barat.

[7] Nazir, N. (2010) 'Analisis Determinan Pendapatan Usaha Kecil di Kota Lhokseumawe', E-Mabis: Jurnal Ekonomi Manajemen dan Bisnis, 11(2), pp. 215-225.

[8] Novrizal, N. (2011) Pengaruh Modal Kerja dan Keragaman Produk Terhadap Keuntungan Pedagang Sayur-Sayuran. Universitas Malikussaleh, Lhokseumawe.

[9] Utami, S. S. and Wibowo, E. (2013) 'Pengaruh Modal Kerja Terhadap Pendapatan Dengan Lama Usaha Sebagai Variabel Moderasi (Survei Pada Pedagang Pasar Klithikan Notoharjo Surakarta)', Jurnal Ekonomi Dan Kewirausahaan, 13(2), pp. 171180. 